
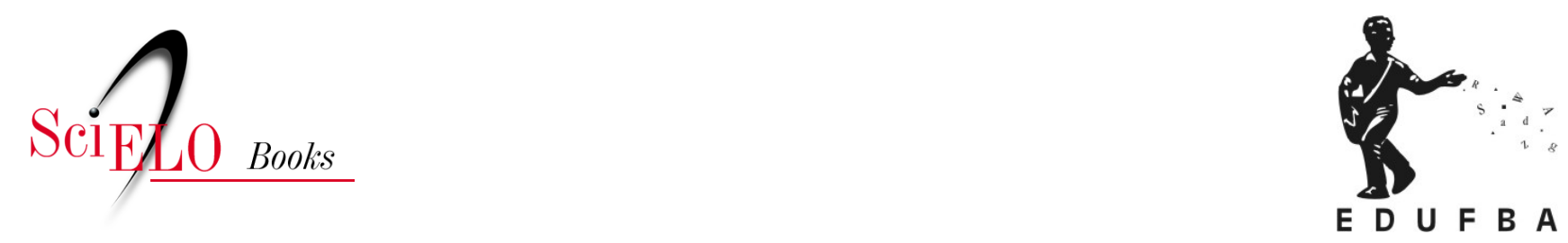

\title{
A música dos bailes
}

\author{
Luciana Xavier de Oliveira
}

\section{SciELO Books / SciELO Livros / SciELO Libros}

OLIVEIRA, L. X. A música dos bailes. In: A cena musical da Black Rio: estilos e mediações nos bailes soul dos anos 1970 [online]. Salvador: EDUFBA, 2018, pp. 237-263. ISBN: 978-85-232-18720. https://doi.org/10.7476/9788523218720.0007.

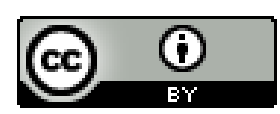

All the contents of this work, except where otherwise noted, is licensed under a Creative Commons Attribution $\underline{4.0 \text { International license. }}$

Todo o conteúdo deste trabalho, exceto quando houver ressalva, é publicado sob a licença Creative Commons Atribição 4.0.

Todo el contenido de esta obra, excepto donde se indique lo contrario, está bajo licencia de la licencia Creative Commons Reconocimento 4.0. 


\section{A música dos bailes}

Dentro do estilo da Black Rio, as formas de fruição da música têm um papel preponderante, e o soul assume a centralidade da cena, pois era primeiramente o consumo musical que fundamentava as mediações comunicacionais no contexto dos bailes. Na impossibilidade de presenciar um baile soul pela distância temporal entre esta pesquisa e o desencadeamento do fenômeno, proponho, como recurso metodológico, analisar um dos discos mais relevantes do período, lançado por uma das maiores equipes de som da época. Além dos altos índices de vendas, a escolha do LP da SGP de 1976 é justificada pela sua celebridade e qualidade, que contribuiu para a manutenção do seu valor e da sua importância ao longo do tempo, sendo reconhecido por fãs brasileiros de black music como um dos mais importantes da cena soul carioca. Esse disco, nos depoimentos com atores da cena, era recorrentemente mencionado como um dos mais memoráveis e, hoje, é considerado um item de colecionador bastante valorizado - é possível encontrar LPs originais por valores que variam entre $\mathrm{R} \$ 120$ e R \$200 no site de leilões on-line Mercado Livre.

$\mathrm{Na}$ tentativa de capturar a atmosfera dos bailes e o entorno midiático no qual essa cena musical se configurou, esse LP também funciona como o registro de um possível set list de um baile, e a análise de cada faixa, bem como a interpretação de elementos visuais que compõem o álbum, é conjugada a 
informações disponíveis nas fontes consultadas sobre os bailes, sobre o mercado musical e sobre a atuação dos DJs de soul. No mercado das coletâneas de soul da época, esse também foi um disco especial, cujo lançamento recebeu grande investimento de marketing por parte da gravadora, a WEA, o que representava os esforços de estabelecer um segmento de mercado expressivo para o soul no Brasil, de forma semelhante ao desenvolvimento e consolidação do gênero na indústria musical dos EUA. Assim, tentarei também construir um panorama geral também sobre a configuração do soul enquanto gênero musical e suas implicações para os processos de identificação das populações negras, tanto nos EUA quanto no Brasil. E no processo de escuta e interpretação desse álbum, por fim, buscarei identificar estratégias de produção de sentido e de circulação midiática, inferindo sobre as mediações e afetos que vinculam esse disco à cena musical, utilizando tanto perspectivas de inspiração musicológica quanto semiótica, articuladas a abordagens sociológicas e históricas, "[...] de modo a oferecer respostas mais complexas sobre as relações de sentido e de sensibilidade que emergem na escuta dos distintos gêneros musicais”. (CARDOSO FILHO, 2014, p. 7) A interpretação da trajetória dessas produções musicais em suas especificidades pode nos oferecer uma chave interpretativa das diferentes maneiras pelas quais a música se materializava nas pistas dos bailes e das cenas musicais, convocando os frequentadores à dança e à celebração por meio da corporificação de diferentes performances e gestos, que também são parâmetros fundamentais do estilo.

\section{Um álbum de equipe}

Uma das maiores equipes de som da cena Black Soul, a SGP desencadeou um novo momento para a cultura black na cidade, realizando bailes em vários bairros da Zona Norte à Zona Sul. Lançando vários discos até os anos 1990, a SGP foi responsável pela introdução na cena Black Soul de novas sonoridades associadas ao soul e ao funk norte-americanos. Foi selecionado o LP da equipe lançado no ano de 1976, auge do movimento Black Rio, quando o empreendimento se transformou em um complexo empresarial de entretenimento altamente lucrativo. Após um disco de relativo sucesso lançado pela Top Tape em 1974, a equipe foi convidada pelo executivo e diretor da Warner 
do Brasil, André Midani, para encabeçar o segmento soul da companhia. A estratégia foi bem-sucedida e o LP da equipe lançado pela WEA recebeu o disco de ouro: "[...] Era uma coletânea de música soul e vendemos mais de 106 mil cópias em poucas semanas. Chegamos à frente do Roberto Carlos". (DOM FILÓ, 2009)

Definitivamente, as coletâneas foram o formato discográfico mais consumido pelo público dos bailes black, e várias outras equipes e DJs também lançaram discos de sucesso. Esse modelo baseado em compilações musicais era composto por gravações de soul e funk previamente selecionadas pelos DJs das equipes e integravam os set lists dos bailes, mostrando-se de antemão bem-sucedidas nas pistas de dança, aprovadas pelos frequentadores, o que diminuía os riscos de não aceitação. Mas, aos poucos, as coletâneas basicamente se tornaram uma estratégia para as gravadoras colocarem em circulação músicas de seus catálogos, divulgando hits de artistas famosos e lançando novos cantores - muitas vezes, as coletâneas de soul eram lançadas antes ou paralelamente aos discos de carreira dos artistas. Para o público, esse formato também era mais econômico, pois, para ter em casa os grandes sucessos dos bailes, não seria necessário comprar um disco de cada artista, e a coletânea também possibilitava o contato e o consumo de diversos estilos e subgêneros contidos em apenas um produto.

Até o final dos anos 1960, os consumidores brasileiros compravam, em geral, mais compactos simples, cujo formato menor barateava o preço. Isso motivava o sucesso de uma determinada canção específica, e não da obra inteira. O maior investimento em coletâneas representava um segundo momento, que refletia um direcionamento mais incisivo da produção fonográfica para o público jovem e de menor poder aquisitivo. Além disso, as produções internacionais eram muito mais rentáveis para as gravadoras, reduzindo gastos em relação ao investimento em artistas locais, já que era mais barato lançar um disco estrangeiro. Assim, evitavam-se despesas com estúdios, músicos de acompanhamento e arranjadores, e o custo maior se referia apenas ao pagamento de royalties para a matriz importada. Não foi à toa que, em 1977, oito meses após sua instalação no Brasil, a WEA já havia realizado 167 lançamentos estrangeiros no país. 
Havia também uma outra diferença fundamental na circulação mercadológica do formato das compilações internacionais. A venda de coletâneas fazia com que os gêneros musicais ganhassem mais importância do que os artistas. Assim, as canções mais famosas, os hits de determinado gênero, recebiam mais destaque do que o artista propriamente. Tanto que, até hoje, os discos de soul ou determinadas canções são decididamente mais lembradas pelos fãs do que nomes de cantores ou bandas menos famosos, ou do que seus álbuns originais. Muitos discos de carreira, de fato, nem eram lançados no Brasil, apenas alguns fonogramas com as músicas de trabalho, que integravam as coletâneas. Tárik de Souza (1976, p. 10) chamava esses lançamentos de "discos de retalho", que continham "mais sucessos por menos centímetros de matéria-prima”. Dessa forma, uma determinada coletânea poderia alcançar uma grande vendagem, enquanto o artista ou banda poderia não lograr da mesma repercussão em seus trabalhos autorais. Isso também aumentava a rentabilidade das coletâneas, que eram produtos mais baratos do que um disco de carreira porque prescindiam de grandes gastos com divulgação e trabalho da imagem de algum artista específico.

Nessa época, alguns discotecários já produziam e mixavam suas próprias coletâneas, como Ademir Lemos e Big Boy, ora colando faixas umas nas outras, sem pausas - no formato non-stop -, ora editando e inserindo efeitos sonoros, vinhetas e vozes, para dar efeito de um set de baile. Era possível também aumentar o tempo de duração das músicas, e muitas coletâneas eram compostas por versões exclusivas de canções norte-americanas, que se tornaram raridades, em muitos casos registrando gravações produzidas especialmente para integrarem as coletâneas brasileiras. O estilo de música que predominava nas coletâneas era o soul-funk; entretanto, em fins dos anos 1970, compilações foram lançadas contendo já alguns sucessos da disco music, refletindo também a opção de algumas equipes que passavam a investir nesse segmento.

As gravadoras trabalhavam a imagem das equipes de som como se elas fossem um "artista" propriamente e ganhavam um status privilegiado não por serem autoras de canções de sucesso, mas por serem “autoras” da seleção dos melhores hits, que davam aos seus bailes um diferencial. Especialmente a Warner, na figura de André Midani, investia fortemente na divulgação dos discos da SGP, organizando grandes festas de lançamento, promoções, 
e comprando bastante espaço publicitário na TV, rádio e jornais. O nome da equipe, que suplantava o nome dos donos ou DJs integrantes, servia como garantia de qualidade e dava aos sucessivos lançamentos de coletâneas assinadas por ela uma regularidade musical, garantindo a consolidação da carreira da equipe enquanto lançadora de sucessos não apenas nas pistas de dança, mas também diretamente no mercado do disco nacional. O primeiro disco da SGP também foi trabalhado como um álbum, mas, diferentemente do que se propunha esse formato discográfico, partiu de uma criação coletiva, que somava o faro da equipe para a escolha de hits com a imposição da gravadora para a divulgação de seu catálogo, levando também em consideração constrições do mercado, valores e gostos da audiência.

A escolha pelo formato LP também representava uma maior lucratividade. Os discos do vinil com 12 polegadas eram inicialmente apenas consumidos por disc-jóqueis, enquanto o público geralmente adquiria compactos ou compactos duplos, de preço menor. A capacidade maior de armazenamento, com cerca de 20 minutos em cada lado, mudou a forma de escutar música e diminuía o custo de produção. Além disso, foi possível se pensar em um conjunto de canções com certa unicidade que passaram a compor os discos, vistos como uma obra musical com unidade estética que "redimensiona o álbum para uma perspectiva em que seu consumo abrange outras esferas sensoriais além da predominantemente auditiva”. (FREITAS, 2013, p. 45) Os álbuns passaram a exigir uma produção mais apurada, a fim de tornar o produto mais atraente, e as gravadoras começaram a investir em projetos gráficos mais elaborados para capas e encartes, que tornavam o disco, em sua materialidade, também uma extensão da imagem e da trajetória midiática do artista, agora visto como um criador de uma obra de arte. Ao assinar suas próprias coletâneas, as equipes, pois, assumiam para si o status de autoras, não referente a uma autoria individual, mas sim a um "autor coletivo". E, de fato, na contracapa do álbum, quem assina a coordenação artística da obra é a própria SGP. Sobre o processo de negociação e lançamento de coletâneas assinadas pela SGP, Nirto e Filó comentam:

O processo de lançamento (de uma música) é realizado em convênio com a gravadora, que traz a matriz, e a equipe, que lança no 
baile. A seleção para o baile é feita na base da qualidade, e a grande preocupação é não viciar o público em termos de comércio. O primeiro contato que fizemos para edição de disco pela Top Tape foi na base de Cr\$1,00 por disco. Agora, a WEA, por intermédio do Sergio Motta e do Mazzola (diretor de catálogo internacional e vice-presidente artístico, respectivamente), entrou em entendimento conosco, nos oferecendo um catálogo da King e da Atlantic para nós selecionarmos um LP. (BAHIANA, 2006, p. 305)

A WEA comprou a Atlantic Records (Atlantic Recording Corporation) em 1967, mas o selo independente havia sido criado 20 anos antes pelos irmãos Ahmet e Nesuhi Ertegün e por Herb Abramson em 1947. Com foco principal em jazz e R\&B, voltada para um público majoritariamente negro, a Atlantic foi responsável pelo lançamento, nos anos 1950, de grandes nomes como Charles Mingus e John Coltrane, integrantes de sua divisão jazzística, e revelou, na mesma época, o mega-astro Ray Charles, o grande percursor da soul music. Segundo Márcio Ribeiro (2003), foi a Atlantic, inclusive, que cunhou o termo "rhythm \& blues" para identificar a música feita por artistas negros, cujos discos até então eram chamados de race records. Os discos da Atlantic possuíam uma produção apurada, e a gravadora recorria aos melhores estúdios do país para a gravação de seus discos - incluindo os estúdios da Stax -, o que a tornou um dos empreendimentos mais bem-sucedidos dos EUA. Também integravam o seu cast Aretha Franklin, Wilson Pickett, Sam \& Dave, Otis Redding e Roberta Flack. A gravadora, posteriormente, passou a diversificar seu elenco, investindo no rock-pop ao lançar grupos como o Vanilla Fudge, Iron Butterfly, Yes e o seu maior sucesso comercial, o Led Zeppelin.

\section{A emergência do soul}

O termo "soul music", em seus primórdios, se referia a um conjunto de sonoridades e musicalidades que utilizavam figuras melódicas e riffs derivados da música gospel e do folk blues, que englobavam a música popular negra no começo dos anos 1960, de acordo com Brackett (2009). O soul era proveniente também do jazz e do R\&B - que se originou da eletrificação do blues, 
com ritmo mais acelerado e instrumentos como guitarra e baixo elétricos-, o que demonstra a interconexão entre diferentes gêneros que compartilhavam abordagens harmônicas, tipos de ritmos, melodias e timbragens semelhantes.

Mas os gêneros realmente se diferenciam, seja pela forma e o grau em que esses elementos são colocados em jogo, seja pelo tema das letras. Assim, a emergência da música soul a partir do rhythm and blues no início dos anos sessenta é mais uma mudança de ênfase do que uma importação de novos elementos da música gospel (como se diz às vezes). Todavia, o crescente emprego de técnicas vocais para significar êxtase espiritual, intensidade e devoção num contexto secular intensificou tanto o senso tanto de identificação apaixonada do cantor com a canção quanto de conexão entre o estilo de música e a comunidade negra. (BRACKETT, 2009, p. 63)

Assim, o soul, como integrante de uma cultura afro-americana de entretenimento, se desenvolveu nos EUA entre 1890 e 1930, a partir da circulação em maior escala do jazz e do blues especialmente em cidades como Nova Orleans, Chicago, Memphis e Nova York - especificamente no bairro do Harlem -, que atraíam tanto uma audiência emergente negra urbana quanto um público branco. (OSTENDORF, 2000) A relação entre o soul e a comunidade afro-americana era um fato concreto, e o desenvolvimento do gênero acompanhou a evolução do movimento pelos direitos civis, dando voz às movimentações culturais e políticas do período, incentivando a conscientização política e racial da população negra norte-americana e chegando também a outros contextos sociais em diferentes países. Além disso, a música acompanhava ainda a própria ascensão social e econômica do negro americano. (SOUZA, 1976, p. 10)

Para alguns pesquisadores, o soul, nos seus primórdios, não se referia essencialmente a um ritmo ou gênero musical determinado, mas dizia respeito a uma forma singular de interpretar canções, cuja terminologia serviria para designar vários aspectos de um ethos afro-americano. (CAVALCANTI, 1981, p. 6) Assim, o soul fazia referência a elementos culturais afro-americanos, como à soul food, culinária específica das comunidades negras do sul dos EUA. E soul music nada mais era que as músicas produzidas pelos negros, 
englobando vários gêneros, e não havia propriamente canções, mas sim intérpretes soul que traduziam o sentimento de uma "alma negra" na forma de cantar com emoção e habilidades vocais peculiares. Mas, aos poucos, o soul começou a se delinear como gênero, ganhando contornos específicos, e "[...] nos anos 70, o termo se generalizou de tal forma, cobrindo estilos tão variados, de Roberta Flack ao Jackson Five, que a única unidade identificável, nesse terreno, está no fato de todos os artistas soul serem negros”. (RISÉRIO, 1981, p. 29)

Dentre as características do canto soul, estava a utilização de melismas sofisticados, progressões harmônicas derivadas do gospel, mas com uma orientação mais pop, presente tanto na recorrência de temáticas amorosas como na adoção eventual de estruturas rítmicas próprias para a prática da dança - em pares ou solo. Ray Charles, um dos primeiros cantores de soul, ganhou fama ao reunir em suas composições elementos do R\&B e do gospel. Reproduzindo inovações já empregadas por alguns cantores menos famosos, como a utilização de padrões de chamada e resposta entre sua voz e conjuntos de metais, ou então alternando com o canto em coro de backing vocals, Ray se inspirava no formato de canções religiosas para compor músicas que falavam sobre temáticas seculares - muitas vezes, substituindo expressões como "Lord" por "baby" -, inserindo técnicas vocais como gritos, interjeições e melismas. (BRACKETT, 2009, p. 63) Sua canção de 1958, "I got a woman”, é considerada por muitos como o marco do nascimento do soul. Recursos semelhantes também foram utilizados por James Brown, cujo canto áspero, exuberante e aberto era semelhante à forma como pastores negros pregavam em seus cultos, exortando os fiéis. Logo, outros cantores que também se identificavam com o soul passaram a empregar outros estilos de canto, mais suaves e sofisticados, como Sam Cooke - que saiu das hit parades negras para alcançar as paradas de pop music, rótulo adotado primeiramente para definir as produções musicais voltadas para o público branco -, em baladas românticas que não apelavam tanto para temáticas sexuais nas letras ou vocalizações.

No começo dos anos 1960, a música soul começava a se distanciar das bases musicais do $\mathrm{R} \& \mathrm{~B}$, começando a assumir características diversificadas e identificáveis a partir da ação de músicos ligados às várias gravadoras 
independentes localizadas em diferentes regiões dos EUA. Apesar de diferenças regionais imprimidas por cada selo nas canções, esses artistas possuíam uma certa coesão, como aponta Brackett (2009, p. 64): "Além dos melismas, bends e amplo espectro de timbres empregados pelos lead vocalists, estas canções, todas em tempo lento, davam destaque a subdivisões em quiálteras, frequentemente articuladas em arpejos de piano ou violão".

Nos centros urbanos de Nova York, Filadélfia e Chicago, o tipo de soul produzido concentrava-se em gravações nas quais o vocal ganhava mais destaque do que o acompanhamento instrumental, em melodias mais suaves, um tipo de sonoridade particularmente trabalhada pela Atlantic. O soul da cidade de Detroit era representado pela Motown, cujo cast possuía nomes de peso do quilate de Marvin Gaye, The Temptations, Smokey Robinson, The Supremes e The Four Tops. As gravações da Motown tinham uma orientação mais pop e mais dançante, com arranjos que utilizavam uma linha de baixo mais forte - incentivando a prática da dança -, vozes suavizadas em modulações sofisticadas e canções de temática romântica, frequentemente incluindo acompanhamentos de palmas e pandeiros, elementos apropriados também da música gospel, que exerciam grande apelo sobre a juventude branca norte-americana.

No sul dos EUA, o soul assumia uma sonoridade mais tradicional, pesada e marcada, com ritmo mais sincopado, vocais crus e inflamados, inspirados nos estilos de canto do blues, e "cozinhas" de metais mais completas, que ocupavam o lugar dos backing vocals, representado pela produção da gravadora Stax, baseada em Memphis, Tennessee. A Stax, deliberadamente, cultivava um soul bem característico, que incluía a colocação dos vocais mais atrás durante a mixagem da gravação em comparação a outros discos de soul da época, privilegiando o trabalho instrumental de conjuntos como Booker T and the MGs e The Bar-Keys. O selo contava ainda com Otis Redding, Carla Thomas, Sam \& Dave, Rufus Thomas e Isaac Hayes - e basicamente seu casting compunha o set list dos bailes e coletâneas lançados por Mr. Funky Santos.

Entre os anos de 1964 e 1966, as técnicas de gospel empregadas pelos lead vocalists continuaram, enquanto os instrumentos acompanhantes adquiriram maior definição através do uso de riffs rítmicos. 
O baixo, em particular, ganhou proeminência através do emprego crescente de padrões sincopados e os metais começaram a ser usados em rajadas sincopadas em staccato. (BRACKETT, 2009, p. 64, grifo do autor)

No início dos anos 1970, influenciados pelo rock psicodélico, cantores como Marvin Gaye (What's going on, Motown, 1971) e Curtis Mayfield (Superfly, Curtom Records, 1972) lançaram os primeiros discos conceituais de soul, cujas temáticas das canções eram baseadas em críticas sociais. O ritmo das faixas possuía subdivisões mais regulares em arranjos mais elaborados utilizando orquestras ou conjuntos de cordas. A questão da temática político-racial já vinha sendo explorada com bastante sucesso em hits de Aretha Franklin, com "Respect" (1967), e "Say it loud - I'm black and I'm proud" (1968), de James Brown, que assinalaram o começo de uma fase mais politizada da música soul.

Nesse momento, o soul já havia se transformado em um termo vago, sinônimo de black music, em processo de absorção por um mercado mainstream, bem assimilado pelas plateias brancas. Artistas influenciados pelo soul agressivo e dançante de James Brown, em uma tentativa de diferenciar-se do soul-pop, passaram a desenvolver uma sonoridade mais radical, com ritmos mais fortes e marcados e arranjos mais "pesados" e complexos, incluindo a utilização de percussão e metais, cujas frases musicais reiterativas permitiam maiores improvisos instrumentais, em uma ligação mais direta com o jazz e o próprio rock. Especialmente Brown estimulou o desenvolvimento de uma estética funk ao introduzir uma percussão pesada e quebras no ritmo (break beats), inserindo nas canções também sons pouco convencionais como gritos, sussurros, distorções na voz (SILVA, 2011), alternando entre falsetes e gritos mais graves, alternados com riffs exuberantes de baixo, guitarra e solos de bateria. As músicas ganharam um andamento mais rápido, com linhas de baixo mais ativas, e tanto a guitarra quanto bateria ganhavam destaque em solos arrojados.

Foi nessa época que a gíria "funky" deixou de ter o significado de algo ofensivo, pejorativo, e passou a designar modos de comportamentos tidos como característicos e positivos dos negros norte-americanos, como gestos, 
roupas, gírias: “[...] tudo podia ser funky: uma roupa, um bairro da cidade, o jeito de andar e uma forma de tocar música." (VIANNA, 1988, p. 20) "Funk" passou a designar as novas produções da black music e passou a ser mais ostensivamente utilizado nos EUA na virada da década de 1960 para 1970. "Na realidade, com a intensa presença do soul no mercado, alguns músicos mais engajados da época passaram a encarar o funk como uma vertente da música negra ainda capaz de produzir uma música, digamos, 'revolucionária”. (HERSCHMANN, 2000, p. 21) Dentre os representantes do funk, destacava-se o guitarrista George Clinton, que, com suas bandas Parliament e, posteriormente, Funkadelic, desenvolveu um tipo de funk mais pesado, influenciado pela psicodelia. Outros grupos de funk que surgiram no período, incluindo Earth Wind \& Fire, Sly and The Family Stone, KC \& Sunshine Band, Kool \& The Gang, Chic, The Gap Band e músicos/cantores como Jimmy “Bo” Horne e Chaka Khan - muitos deles gravaram grandes sucessos da disco music. Os primeiros trabalhos dos Jackson Five também fazem parte dessa categoria.

Outra vertente do soul, de estilo mais suave, inspirado na Motown e nas baladas românticas de cantores como Curtis Mayfield, foi o chamado Philly soul, originário do estado da Filadélfia. Representado por bandas como Harold Melvin \& The Blue Notes, The O'Jays e The Stylistics e pelo músico Billy Paul, o soul da Filadélfia era profundamente marcado por arranjos de cordas e metais em gravações mais dançantes, mas ligeiramente mais lentas, em que as vozes eram registradas com mais "limpeza" e nitidez, com um apelo mais pop. Essa sonoridade foi desenvolvida nas gravações lançadas pelo selo Philadelphia International Records, fundada em 1971, que eram marcadas por arranjos orquestrais, linhas de baixo bastante marcadas e percussão vigorosa em canções animadas e vibrantes. "O som característico de bateria enfatizava os médios e frequentemente acentuava cada batida”, como considera Brackett (2009, p. 66), influenciando a disco music na década de 1970 ao apresentar canções mais "melosas" e mais "bem comportadas" em relação a outros estilos de soul e funk. Ao lado das seções de sopro e cordas dos arranjos, que concediam certo refinamento e sofisticação, eram contrapostos teclados e sintetizadores, que davam um tom mais moderno às composições, apesar de serem mantidas as estruturas musicais tradicionais. Os produtores Kenneth "Kenny" Gamble e Leon Huff criaram a marca do Philly soul dentro 
da gravadora, compondo e produzindo canções precursoras do estilo, como "I love music" (1975), dos The O'Jays, "The love I lost" (1973), de Harold Melvin \& the Blue Notes, e "The Sound of Philadelphia (TSOP)" (1973), do conjunto Mother, Father, Sister, Brother (MFSB), trilha sonora do programa norte-americano Soul Train.

A SGP, representada pela figura do DJ Luizinho - ou melhor, Luizinho Disc-Jockey Soul -, foi responsável pela introdução do Philly soul na cena dos bailes black cariocas. Luiz Stelzer era um jovem branco apaixonado por soul. Começou sua carreira discotecando em boates da Zona Sul e sua fama cresceu. Luizinho garimpava novidades dançantes entre os discos promocionais dispensados pelos DJs de outras casas, o que garantia originalidade a seu trabalho. Logo recebeu um convite dos donos da SGP, que foram até a discoteca onde o jovem DJ tocava. Luizinho recusou o convite, mas a SGP não desistiu e ofereceu como pagamento adiantado um fusca. Diante da proposta irrecusável, o DJ finalmente aceitou ingressar na equipe como disc-jóquei principal, na qual permaneceu alguns anos até fundar sua própria equipe, a Power Som, atuando também com produção de rádio, lançando algumas coletâneas de sucesso e montando um equipamento de alta qualidade que alugava para outros eventos, como a sonorização do Carnaval na Avenida Rio Branco, Centro do Rio.

\section{Uma black em uma moto}

A capa tinha uma black em cima duma moto - um negócio revolucionário na época. Dom Filó ${ }^{12}$

O primeiro LP da SGP também marcava a entrada da Atlantic no mercado brasileiro, e seu catálogo de artistas serviu como fonte para a compilação das faixas que compuseram o disco da equipe. A WEA, detentora dos direitos e distribuidora da Atlantic no Brasil, investiu na qualidade do álbum, cuja capa dupla foi ilustrada pela dupla de artistas plásticos Walney de Almeida

12 Em entrevista a Edson Lopes Cardoso em 2009. 
e Miranda de Almeida, que também atuavam em publicidade. Walney, especialmente, também integrava o departamento cultural do Clube Renascença e era amigo de Nirto e Dom Filó, participando ativamente das atividades do clube, como a produção da peça Orfeu da Conceição e de rodas de samba, bem como da cena da Black Rio. O design gráfico ousado da capa tinha inspiração na arte psicodélica, abusando das cores fortes e formas abstratas, bem como de desenhos surrealistas de inspiração onírica, em um traço próximo à Pop Art. Esse tipo de ilustração, baseada na superposição de imagens e cores contrastantes e saturadas, com efeito caleidoscópico ou "lisérgico" era bastante usado também em capas de disco de rock da época e tinha relação com os movimentos contraculturais jovens dos anos 1960 e 1970. Um exemplo foram as capas de discos célebres como Sgt. Pepper's Lonely Hearts Club Band, de 1967 - criada por Peter Blake, um dos fundadores da Pop Art -, e Yellow Submarine, de 1969 - do artista tcheco Heinz Edelmann. Grupos de funk e soul também adotaram o visual psicodélico nas capas de seus LPs, como Kool \& The Gang (Spirit of the Boogie, 1975) e The Dramatics (Whatcha See Is Whatcha Get, 1971). No Brasil, as capas dos álbuns Jorge Ben, de 1969, criada pelo artista plástico Albery, Jardim Elétrico (1971), dos Mutantes, e o primeiro disco de Caetano Veloso, de 1969, seguiam essa tendência.

A capa do disco da SGP também fazia eco às capas de discos de soul norte-americanos, em que personagens negros ganhavam destaque principal na narrativa visual. A célebre capa do disco de compilação de canções de sucesso de Marvin Gaye, Super Hits (1970), mostrava um super-herói negro salvando uma mocinha também negra, com cabelo afro, ao estilo das HQs. Havia uma demanda clara por parte do público negro em adquirir produtos nos quais eles se vissem e se sentissem diretamente representados, assumindo posições protagonistas, tanto nos EUA quanto no Brasil. Um jovem negro universitário confessou para Lena Frias (1976, p. 4): “[...] mas o que sei é que tem gente nas bocadas que nem compra mais discos de soul se, na capa, aparece branco". Esse consumo afirmativo era tão decisivo que, temeroso por ter seu disco rejeitado, o DJ Luizinho (ou Luizinho Disc-Jockey Soul), ao lançar seu disco O som dos blacks (1977, RCA), pintou metade do rosto de preto, em um "meio" blackface que tentava demonstrar sua afiliação não apenas ao movimento black, mas a uma identidade negra globalizada - também representada 
no uso de uma cartola com as cores da bandeira americana-, acionando ainda o valor da mestiçagem que garantiria a partilha dessa negritude.

A capa do álbum da SGP tinha também um certo tom futurista, presente nos traços da ilustração que lembrava cenas de viagens espaciais e imagens sobrenaturais, à semelhança da capa do álbum Mothership Connection (1975), do grupo de funk Parliament, ilustrado com uma foto-montagem protagonizada pelo personagem de um cafetão negro - segundo palavras do líder do grupo, George Clinton -, com roupas prateadas e botas de plataforma em uma nave interestelar sobrevoando o espaço. Fã da série de ficção científica Star Trek, em entrevista ao site Soul Train, Clinton explicou o que motivou a criação da capa: "Nós colocamos pessoas negras em situações em que ninguém jamais pensou que elas poderiam estar, como na Casa Branca. Eu imaginei outro lugar que nunca se imaginou que um negro poderia estar, que foi o espaço sideral”. (CLINTON, 2015) Outras capas de LPs de artistas de soul e funk norte-americanos da época eram também inspiradas nessa estética afrofuturista como Super Hits (1970), de Marvin Gaye, e Spirit of the Boogie, do Kool \& The Gang (1975).

A capa do LP da SGP também pretendia apresentar uma nova representação da negritude, baseada em uma estética afrofuturista, desestabilizando concepções fixas de identidade negra, baseadas em visões tradicionais ou folclóricas, pela articulação com signos da contemporaneidade, como a ficção científica e a exploração espacial com cosmologias africanas. O afrofuturismo se refere a um conjunto de manifestações culturais, compostas pela criação de narrativas fictícias ligadas a um futuro imaginário, em que negros são representados em um universo de referências ligadas à alta tecnologia e à ficção científica - em oposição à localização cultural dos povos africanos e descendentes em um passado primitivo. Criado na década de 1960, o afrofuturismo ajudou a transformar alguns paradigmas de representação e também apresentava uma crítica aos estereótipos e à representatividade negra nos produtos midiáticos, na arte, na moda e na literatura.

Seguindo essa tendência, a ilustração da mulher negra pilotando uma moto voadora representava a apropriação de uma iconografia cinematográfica da ficção científica como a ópera espacial 2001: uma odisseia no espaço (1968), dirigido por Stanley Kubrick; Barbarella (1968), dirigido por Roger 
Vadim; ou a franquia Star Wars (1977), dirigida por George Lucas. Para além de uma simbologia mágica e supernatural, a ilustração também acionava signos de transcendência, liberdade, êxodo e paz, representados por imagens como borboletas - um símbolo usual do movimento hippie -, estrelas, flores e a pomba branca voando ao lado da logo com o nome da equipe, cuja fonte das letras também apresenta um design futurista. A ideia de transformação estava presente também na grande bolha estourada, de onde sai a mulher na moto. E sua indumentária ainda trazia elementos do estilo black, como botas de plataforma (botas aladas), roupas coloridas com mangas boca de sino em estampas psicodélicas, numa imagem que conectava o disco a um conjunto de símbolos modernos e globalizados. Essas sensações e referências representadas na capa poderiam ser acionadas a partir da audição do álbum e, por conseguinte, pela ida aos bailes da equipe. Esse convite estava representado na presença de uma grande foto, de autoria de José Moura, de um dos bailes da SGP impressa na contracapa do álbum.

\section{O LP faixa a faixa}

Com 11 faixas, cinco do lado A e seis do lado B, a primeira canção do disco, ${ }^{13}$ "It's all right now", era um hit do cantor Eddie Harris, que começou sua carreira como saxofonista de jazz, e seu primeiro álbum, Exodus to Jazz (1961), alcançou as paradas de sucesso. Nos anos 1960, foi contratado pela Atlantic Records, em que começou a gravar canções que promoviam uma mescla entre o jazz e o funk, em trabalhos mais comerciais, ampliando seu público. Suas experimentações musicais, introduzindo novos instrumentos, chamaram a atenção da crítica, e Harris passou a inovar, influenciado também pelo blues e pelo rock. Essas mesclas transformaram o músico em um referencial para as futuras gerações de músicos do fusion jazz e da house music.

A faixa "It's all right now", que integra o disco That is why you're overweight, de 1975, é um "funk semi-instrumental”, swingado, em que os vocais são desempenhados por um coro que repete o único verso da canção ao longo de

13 O LP na íntegra está disponível para audição na plataforma de compartilhamento de vídeos Youtube no link: <https://www.youtube.com/watch?v=V6F4sxQAR7s>. 
3 minutos e 53 segundos, intermediado por algumas frases e interjeições entoadas pelo cantor, entremeadas por solos de saxofone e palmas, quando a canção vai chegando ao final. De andamento mais lento, é uma gravação apropriada para o começo dos bailes, criando uma ambiência para hits mais agitados.

A próxima faixa, "Love your life”, também tinha um andamento mais lento, mostrando uma intercessão entre o soul e a disco. A canção era do grupo escocês Average White Band - que possuía apenas dois músicos negros -, que, no ano de 1975, vendeu mais de um milhão de discos, liderando as paradas de sucesso norte-americanas até o final da década e atingindo tanto plateias brancas quanto negras. A canção selecionada para integrar a coletânea da SGP integrou o álbum Soul searching (1976), que ficou em segundo lugar nos charts de soul da Billboard Magazine e ganhou disco de ouro. "Love your life" fala sobre autoestima e amor próprio, utilizando ritmo mais dançante em uma batida contundente que aproxima a canção da disco music. Gênero também presente na coletânea pela inclusão do hit "Treat me like a woman" (1976), da cantora Jackie Carter, canção título do seu LP de estreia. Carter era uma cantora de estúdio e fazia parte do grupo alemão Silver Convention, um dos grandes nomes da euro disco. "Treat me like a woman" foi composta por Frank Diez, um dos mais talentosos guitarristas alemães do período, que também trabalhou com Donna Summer e contou como arranjos orquestrais do músico erudito alemão Peter Herbolzheimer. Arranjos orquestrais compunham uma das características principais da disco music, com a utilização de instrumentos de cordas (em particular, o violino), pianos e metais, uma influência notória das gravações da Motown. Já as linhas do baixo elétrico são herdeiras do funk, e há uma ênfase no canto em falsete, o que propiciou o surgimento de novos timbres de cantores com vozes mais suaves. Especialmente "Treat me like a woman" possui uma base dançante, com arranjos orquestrais bastante semelhantes ao trabalho de Isaac Hayes na canção tema do filme Shaft, que surgem em um crescente, combinadas a uma maior ênfase no baixo e na bateria, o que dá à canção um efeito dançante e luxuriante, estimulando especialmente o movimento dos quadris. Jackie Carter também utilizou o recurso de pronunciar algumas interjeições, murmúrios e gemidos, entremeando os versos da canção, que dá uma atmosfera sensual e relembra a 
estética "orgásmica" de "Love to love you baby", sucesso de Donna Summer lançado em 1975, cheia de sussurros e gemidos.

A quarta faixa é um medley do grupo vocal americano de soul Archie Bell \& The Drells, gravado exclusivamente para o LP da SGP com duas canções: "I can't stop dancing" e "Tighten'up", regravações de dois sucessos do grupo dos anos 1960, consideradas canções precursoras do funk. O grupo também aderiu ao Philly soul, gravando canções mais suaves, em oposição ao deep soul (ou southern soul), estilo de soul mais energético e agitado que marcou o início da carreira e tinha relação com a origem do grupo, criado em Houston, no Texas, sul dos EUA. A última canção do lado A do LP é “I don't want to lose you”, do conjunto Jimmy Castor Bunch. A banda liderada pelo saxofonista americano Jimmy Castor transitava entre o doo-wop, passando pelo soul, funk e também música latina. O músico foi pioneiro ao introduzir no R\&B camadas percussivas, utilizando também muitas guitarras distorcidas em seus arranjos. Seu disco Troglodyte (Cave man), de 1972, precedeu a explosão do funk na metade da década, e a faixa-título continha um discurso bem-humorado que foi sampleado diversas vezes e inspirou a primeira geração do rap americano nos anos 1980.

As baladas românticas soul também tinham espaço nos bailes, geralmente sendo tocadas após uma sequência mais agitada, a fim de que os casais pudessem dançar juntos ao som de uma música mais lenta - uma oportunidade para “o encontro dos sexos, o início de namoros, o flerte mais 'oficializado". (VIANNA, 1987, p. 100) Ras Adauto, em entrevista à autora em 21 de fevereiro de 2016, relembra: "aquela era ainda a época de namorar certinho, a gente ia para o baile para paquerar mesmo. Depois levava a menina em casa, namorava no portão. Muita gente casou depois de se conhecer nos bailes". Isso, de certa forma, contradiz uma ideia de que a cena Black Rio era uma adaptação da contracultura à vida suburbana, que mantinha ainda parâmetros de sexualidade e padrões de relacionamento tradicionais, não incorporando fortemente novas tendências comportamentais da revolução sexual, em que homens e mulheres ainda desempenhavam papéis bastante definidos de gênero e sociabilidade. Alguns momentos possibilitavam uma oportunidade de subverter regras, como nos bailes chamados de Noites da Maria Cebola, por exemplo. Nesse formato de baile, bastante popular nos anos 1970 em várias partes do Brasil, 
as mulheres tiravam os homens para dançar no momento da música lenta. A moda também chegou aos bailes de soul, como conta Oziléia Souza, em entrevista à autora em 26 de abril de 2016: "era tudo muito respeitoso, e eu só saía com meu irmão, mas nas noites da Maria Cebola era uma oportunidade para conhecer rapazes. As meninas na época eram mais recatadas, e oflerte ficava difícil, só as mais avançadinhas que tinham coragem".

O lado B do vinil é encabeçado pela instrumental “Ju Ju Man”, única música "brasileira" do álbum. Era uma regravação de uma música do grupo alemão Passport, conjunto de jazz fusion liderado pelo saxofonista e pianista Klaus Doldinger, criado em 1971, que também fazia parte do elenco da Atlantic. A canção - cuja grafia original era "Ju-Ju-Man” - foi lançada no disco do grupo, também de 1976, Infinity machine. Para o LP da SGP, a canção de mais de dez minutos foi reduzida para três minutos e ganhou um "tempero" brasileiro com a introdução de apitos e ataques percussivos em instrumentos como atabaques, congas e timbales, reproduzindo alguns toques típicos do samba, em diálogo com a bateria. O saxofonista Oberdan Magalhães foi convocado para montar um grupo especialmente para essa gravação - a Hot Stuff Band -, que teve como base o conjunto Azymuth - também contratado da WEA -, formado por músicos de estúdio experientes que tocavam com grandes nomes da MPB. Assim, a regravação de "Ju Ju Man” contou com Oberdan no sax, Márcio Montarroyos e Darcy da Cruz nos trompetes, José Roberto Bertrami nos teclados, Alexandre Barbosa (Mamão) na bateria, Alex Malheiros no baixo e na guitarra, Wilson das Neves na percussão, entre outros músicos. O grupo chegou a se apresentar ao vivo poucas vezes, em shows realizados em bailes da SGP, variando os integrantes, como Chico Batera, Jamil, Cristóvão Bastos, Edson Maciel, Cláudio Stevenson e Barrozinho, segundo Motta (1976, p. 38). A Hot Stuff Band não teve continuidade, mas serviu como inspiração, em termos de mistura e experimentação musical, para a criação da Banda Black Rio, naquele mesmo ano.

“Ju Ju Man”, inicialmente composta como uma peça de jazz fusion, misturava elementos do jazz, do soul e do rock. A guitarra elétrica é a referência principal, ao lado do baixo elétrico, que ganha destaque em solos vigorosos. A bateria também ganha espaço com pulsação mais próxima ao rock do que a gêneros tradicionais do jazz, como o bop. A influência de Miles Davis 
é notável, já que o músico foi um dos precursores do fusion, antes chamado de jazz-rock, especialmente pela substituição dos instrumentos acústicos pelos eletrônicos, abrindo mão da improvisação para dar lugar a ritmos mais quadrados, reiterativos e dançantes. A introdução de sonoridades e timbragens afro-brasileiras na gravação despertou o interesse do Passport, que, no ano seguinte, fez um disco em homenagem ao Brasil (Iguaçu, 1977), que contou com a participação de vários músicos brasileiros - dentre eles, o baterista Wilson das Neves.

A música mais famosa do álbum é "Respect", de Aretha Franklin, a segunda faixa do lado B, que parece ter sido propositalmente escolhida para representar o ponto alto do baile. O hit lançado em 1967 e composto por Otis Redding é o maior sucesso de Aretha Franklin, que se tornou também uma espécie de hino do feminismo e do movimento pelos direitos civis nos EUA. A letra, escrita por Redding, teve seu eu-lírico modificado do masculino para se adequar à voz feminina, em que a cantora exigia respeito de seu companheiro, cujo canto revelava aspectos da técnica vocal do gospel, exortando as audiências a cantar e a agir. A canção foi incluída no disco de estreia de Aretha na Atlantic, I never loved a man the way I love you (1967), liderando as paradas de sucesso, tanto de $\mathrm{R} \& \mathrm{~B}$ quanto de pop, durante várias semanas. A "rainha do soul" iniciou sua trajetória cantando jazz, mas aderiu ao soul ao assinar contrato com a Atlantic em 1966, lançando inúmeros discos de sucesso, considerados clássicos pela imprensa especializada, e que fizeram com que Aretha vendesse mais discos do que qualquer outro artista negro norte-americano. (BRACKETT, 2009, p. 65)

A canção seguinte, "The ghetto", de Donny Hathaway, era mais uma faixa que demarcava a afiliação ao soul clássico da SGP. Uma versão reduzida, com cinco minutos e um pouco diferente da original (com sete minutos), foi selecionada para integrar a coletânea. A canção, cuja letra nada mais é do que uma sucessiva repetição da expressão "the ghetto", é entremeada por frases, interjeições e sons que reproduziam as sonoridades das ruas de um bairro negro, como conversas e o choro de um bebê. A batida dançante era inspirada no latin jazz, especialmente presente na utilização de congas cubanas. Hathaway era um músico e compositor talentoso, trabalhou com importantes nomes do soul, como Aretha Franklin e Curtis Mayfield, e teve uma curta 
trajetória, falecendo precocemente aos 33 anos, em 1979. Mas foi uma das grandes sensações da soul music, com sua voz suave de inflexão gospel e romântica. Seus duetos com Roberta Flack fizeram enorme sucesso - "Where is the love" (1973) e "The closer I get to you" (1978). Donny Hathaway era um representante do soul de Chicago, um estilo mais suave em relação ao hard soul ou ao southern soul. Apesar de manter a influência do canto gospel, as gravações seguiam harmonias mais doces e descontraídas, com cantores altamente melodiosos e com um apelo mais pop. Outros artistas associados ao soul de Chicago eram Chaka Khan, Earth, Wind \& Fire e The Emotions.

"If you can't be in love" (1976) é outra canção lenta e romântica do disco da SGP. Os Spinners começaram sua carreira em Detroit, sendo contratados inicialmente pela Motown, depois indo para a Atlantic. Foi um dos grupos vocais de $\mathrm{R} \& \mathrm{~B}$ mais famosos do período, considerado representante do easy listening, pop orquestral, ou da chamada adult contemporary music, rótulos que englobavam baladas mais lentas e suaves, que podiam servir de fundo musical relaxante e agradável. Na mesma chave melódica, a próxima canção do álbum, "Grateful" (1976), do quinteto vocal Blue Magic, um dos principais conjuntos do Philly soul, também é uma balada romântica, cantada em falsete, uma marca das canções do período, ao estilo do cantor Barry Gibb, dos Bee Gees, e do grande ícone do soul Al Green. A última canção do álbum é outra gravação de Aretha Franklin, "Until you come back to me”, lançada no ano de 1973, que posteriormente integrou o álbum da cantora Let me in your life, em 1974, que teve participação do músico brasileiro Eumir Deodato, tocando piano elétrico. Composta por Morris Broadnax, Clarence Paul e Stevie Wonder, vendeu um milhão de cópias nos EUA.

\section{Música altamente dançável}

Não apenas os discos da SGP, mas todas as coletâneas assinadas pelas equipes eram compostas por músicas americanas, não havendo espaço para cantores brasileiros. Como discutido anteriormente, o consumo de discos importados era uma marca da cena black carioca, não só em resposta à penetração no mercado nacional de música estrangeira. Mas demarcava também um impulso distintivo a partir do contato com uma produção globalizada, 
cosmopolita, anglófona, em que o inglês era compreendido como a língua que possibilitaria um ingresso na modernidade ocidental. No entanto, quase não existia conhecimento no idioma entre os participantes dos bailes, que ouviam e dançavam os sucessos do soul e do funk sem atentar para o conteúdo das canções, mais interessados no ritmo e na prática da dança. André Garcia Braga (2015), em sua tese sobre a circulação de vinis no contexto da Black Rio, transcreve o seguinte diálogo, que ilustra bem a relação dos frequentadores dos bailes com a questão do inglês.

Andre: Vocês entendiam as letras das músicas em inglês ou procuravam saber ou traduzir elas [sic]?

DJ Ricardo: Eu nunca entendi nada, ninguém sabia nada. Eu não sei inglês até hoje... a gente cantava o que achava parecido. Mas o que interessa mesmo é o ritmo, a batida, a letra não importa... Andre: Nem nas músicas conhecidas do James Brown?

DJ Ricardo: Olha, James Brown é bom pra dançar. As músicas que mais bombavam nos bailes eram 'Pick Up The Pieces', 'Pass The Peas' e 'Sex Machine' e eu acho que nenhuma delas tem essa mensagem racial. Mas podia tocar qualquer uma do James Brown ou dos JBs que o salão vinha abaixo, independentemente de ter ou não uma mensagem racial. (BRAGA, 2015, p. 104-105)

Partilhar a escuta de canções, mesmo que a mensagem contida nas letras não estivesse acessível, dançar, paquerar, consumir bebidas, dividir um espaço e performatizar um estilo faziam também parte do ritual dos bailes black, que eram deliberadamente espaços para a manifestação de um sentimento compartilhado dos sentidos criados em torno do que significava ser jovem e negro - no contexto da cena musical. A celebração e a festa possibilitavam a experiência musical e o exercício de novas sociabilidades por meio do corpo e da dança, pois a música jovem é, acima de tudo, dançável. (TROTTA, 2006, p. 34) No contexto da cena da Black Rio, a mensagem musical não era o principal, pois o vetor da juventude se encontrava depositado no ritmo, que era a base sensorial para a partilha de sensibilidades em torno de uma ideia de juventude - e, no caso do soul, de negritude - como aponta Trotta (2006, p. 34): 


\begin{abstract}
Musicalmente, a música jovem apresenta uma forte base rítmica que quase sempre reforça a pulsação, isto é, seus desenhos rítmicos são articulados nos pontos de apoio do compasso. O amor simples e idealizado do jovem e a batida energética da base rítmica se completam com uma estrutura harmônico-melódica direta, com poucos elementos de contraste e/ou quebra de expectativas. Todos esses elementos musicais são reforçados por uma atitude dos artistas que colaboram para uma valorização da 'energia', da 'vida' e da 'felicidade’, representadas na estética jovem.
\end{abstract}

A música jovem também é reiterativa, o que favorece a performatização de passos de dança e o engajamento corporal de maneira criativa e espontânea. O corpo, nos bailes soul, se tornava um documento que assinalava uma identidade negra acionada na dança e nos gestos, mobilizando a exibição de uma subjetividade construída. A performance e o estilo efetivado por meio de um conjunto variável de mediações permitiam, pois, a corporificação e materialização de uma identidade no engajamento do corpo na dança, que tornava sensível a consciência da diferença. A música juvenil se mostra, dessa maneira, como um territorio fundamental de produção de estilos e de atos críticos, enfatizando conflitos e diferenciações que não podiam mais ser ocultadas.

Em um primeiro momento, os bailarinos tentavam copiar os passos de celebridades como James Brown, Michael Jackson, Tony Tornado e Gerson King Combo em danças mais individualizadas e improvisadas, que recorriam, frequentemente, a formas de movimentação mais associadas a posturas masculinas, como braços esticados, chutes, meneios dos joelhos e pés, passos aéreos e acrobacias energéticas, abrindo espaço para a criatividade dos dançarinos. Um dos passos mais executados era o "espaguete", um "abrasileiramento" para spacatto, também chamado de grand écart - nomenclaturas ligadas ao universo do balé -, que consistia na abertura total das pernas, uma para frente e a outra para trás, até o chão, movimento que exigia bastante esforço e flexibilidade. Para facilitar o deslizamento dos pés no chão da pista, muitos dançarinos aplicavam graxa às solas dos sapatos, ou então, como mencionado anteriormente, fixavam chapas de metal aos saltos que facilitavam a execução do passo chamado "agilidade no sabonete”. (RISÉRIO, 1981) 
O dançarino Nelson Triufo, um importante personagem da cena black de São Paulo, narra como os passos de funk foram introduzidos nos bailes:

Na época para a gente a dança não tinha muita técnica, digamos que a gente olhava os movimentos e copiava, depois que começamos a entender que existiam contagens, os aquecimentos, na época a gente não se aquecia não, já chegava dançando, o aquecimento era a própria dança, hoje não, hoje tudo é mais técnico, antes era mais uma forma de tirar um barato, curtir, apesar de já estar aparecendo em televisão, mas hoje não [...]. (COLOMBERO, 2011, p. 7)

Os passos de dança executados nos bailes brasileiros eram mimeses de danças de rua negras norte-americanas, como o locking, estilo de dança criado pelo bailarino e coreógrafo Don Campbell - também conhecido pelo nome artístico Campbellock -, que fazia parte do elenco de dançarinos do programa Soul Train. O locking foi inspirado nos passos do funky chicken, dança popularizada pelo cantor de soul Rufus Thomas, que lançou a canção "Do the funky chicken" (1969) e se baseava em movimentos ritmados laterais de quadril e joelhos, que se abriam e fechavam, conjugados com elaborados giros com os braços. ${ }^{14}$

Geralmente, as danças de rua ou danças populares negras norte-americanas permitiam mais improvisações e introdução de traços particulares, com mais liberdade. Foi o que ocorreu com as danças ligadas ao funk e ao soul, a exemplo do locking. Don Campbell não conseguia executar adequadamente os passos do funky chicken com fluência e rapidez e acabou desenvolvendo um estilo de dança cujos passos amplos e acrobáticos eram executados de modo interrompido, contraindo os membros como se eles estivessem sendo travados (locking). As pausas acompanhavam os tempos fortes das batidas do funk, congelando as modulações corporais, que eram executadas com

14 O funky chicken foi baseado na dança the chicken, bastante popular nos EUA na década de 1950, em que os dançarinos batiam os braços, rebolavam e movimentavam os joelhos, em uma espécie de imitação de uma galinha. Uma versão dessa dança ficou conhecida no Brasil através do apresentador de TV Gugu Liberato, na ocasião da gravação da música "Baile dos passarinhos", no começo dos anos 1980 . 
extrema rapidez e em continuidade. Campbell acabou por criar um dos primeiros grupos de street dance de que se tem notícia, o The Lockers, em Los Angeles. Seus passos de dança influenciaram toda uma geração e inspiraram também a coreografia de John Travolta em Saturday night fever (1977), já durante a era disco. A partir do locking, outras danças foram sendo criadas, como o roboting ou robot shuffle - no Brasil, os blacks chamavam a dança de "o robozinho" -, que reproduziam os movimentos mecânicos de um robô, com braços contraídos e pernas esticadas, sem articular os movimentos. Já o popping foi criado por Sam Solomon (Boogaloo Sam), na Califórnia, cujos movimentos eram baseados em rápidas contrações e relaxamentos dos músculos, que empurravam o corpo do dançarino em impulsos bruscos sincronizados com as batidas da música (ou pops), de forma contínua e combinada com vários outros movimentos e poses. Esse estilo de dança foi popularizado em todo o mundo por Michael Jackson e também possibilitava a realização de acrobacias, saltos, giros no chão e movimentos de joelhos.

Essas danças básicas passaram a incluir movimentos característicos da dança de rua que são praticados até os dias de hoje, como os waves - em que ombros e braços esticados em linha realizam um movimento ondulatório em continuidade -, boogaloos ou boog style - movimentos mais fluidos e circulares, que davam a ilusão de um corpo sem ossos ou com articulações moles e soltas, que envolvia tremulações de cabeça, quadris e joelhos, bem como deslocamentos e caminhadas em passos mais elaborados -, o passo the running man - em que o dançarino simula uma corrida sem sair do lugar, deslizando os pés no chão e jogando os braços flexionados para frente e para trás - e o famoso moonwalk, eternizado por Michael Jackson, inspirado em passos já praticados na comunidade afro-americana desde os anos 1930. O moonwalk - também chamado de backslide - faz parte de um conjunto de técnicas que criam a ilusão de que o bailarino está flutuando sobre o chão, deslizando os pés, como se caminhasse para trás.

Esses passos e movimentos mais célebres e complexos eram performatizados por dançarinos mais experientes e talentosos dos bailes, pois exigiam certo treino. Muitas vezes, abriam-se rodas no meio da multidão para que um determinado bailarino solasse no centro do espaço, uma prática usual também em outros contextos brasileiros populares, como o samba de roda 
e o jongo, como lembra Vianna (1987, p. 96): "O solista escolhe quem vai substituí-lo no centro. Esse é o único momento do baile em que aparece o dançarino solo, mesmo assim rodeado por um grupo de amigos, que também controla o tempo de sua dança 'solitária”. A performance da dança, assim, ganhava contornos coletivos e individuais ao mesmo tempo. O centro da roda era o espaço para a execução dos melhores passos, e, geralmente, o bailarino puxava pelo braço o próximo que irá ocupar seu lugar, sucessivamente. Essa prática dava destaque aos dançarinos mais habilidosos, que chegavam a ficar famosos e, eventualmente, podiam ser convidados pelas equipes para dançar profissionalmente nos bailes, incentivando também o surgimento de novos talentos por meio dos concursos de dança. As coreografias criativas também acompanhavam, dentro e fora dos bailes, a criação de comprimentos elaborados e gestos que identificavam os blacks entre si e que distinguiam também os seguidores de cada equipe, que funcionavam também como espécies de associações ou clubes.

Mais negros chegam e se cumprimentam num ritual de gestos, punhos tocando-se ligeiramente dentro de uma sequência mímica, tanto mais complicada quando maior é o conhecimento das pessoas ou dos grupos entre si. O mais simples é apertar fortemente a mão do parceiro, por baixo, um segurando o polegar do outro. (FRIAS, 1976, p. 5)

Posteriormente, começou a chegar aos bailes cariocas a tendência das coreografias coletivas, mais simples, em que os dançarinos se posicionavam em linhas para executar os mesmos passos em sincronia. A popularização desse formato pode ter vindo dos grupos que acompanhavam as equipes, como o Angola Soul, ou de grupos formados por dançarinos amadores, que se reuniam para participar de concursos e acabaram ganhando fama e se profissionalizando. Foi o caso do Grupo Philadélfia, formado por Walter Bastos, Ricardo Sampaio, Edson Rocha e Marcus Vinicius, que venceu vários campeonatos e começou a se apresentar artisticamente em bailes soul. Com idades que variavam entre 21 e 26 anos, esses jovens passaram a atuar profissionalmente na cena black, elaborando coreografias que eram copiadas pelos fãs, executadas ao som de grupos de soul como The Tramps e The Commodores 
- conjunto então liderado pelo cantor Lionel Ritchie. O grupo também realizava dublagens de canções americanas de sucesso.

A execução de coreografias coletivas também era uma tradição em comunidades negras americanas, chamadas de soul line dances e também de Chicago steppin. As line dances consistiam na repetição coletiva de sequências de passos de dança de forma sincronizada, com os dançarinos alinhados e voltados para a mesma direção - cada grupo podendo conter várias filas, uma em frente à outra -, e a sequência coreográfica tem a duração de uma canção. Esse tipo de dança se desenvolveu nos EUA, influenciado pelo madison, estilo do final dos anos 1950 praticado por jovens ao som do rock'n'roll e jazz. Na década de 1970, as line dances praticadas ao som da country music se tornaram uma febre e acabaram também por chegar às pistas das discotecas e às vizinhanças negras, que adotaram a prática da dança ao som do soul e do funk. Já o Chicago steppin, ou apenas steppin, foi uma dança urbana de salão criada nos bairros negros de Chicago também na mesma época, influenciada pelo lindy hop e pelo swing dance, utilizando os mesmos giros e pegadas, mas sem piruetas, em um ritmo mais lento. A dança é praticada por pares, em oito compassos, que se encaixam na batida $4 / 4$ do R\&B e também da disco music, e influenciou a criação do hustle, dança praticada por pares nas pistas das discotecas. Chamadas no Rio de Janeiro de "passinhos", essas coreografias coletivas se tornaram a marca do posterior movimento Charme, durante os anos 1980 e 1990, praticadas até os dias atuais, e também fizeram parte do movimento do funk carioca em seus primórdios, quando ainda se dançava o funk melody, de batida menos acelerada, mais apropriada para a prática da dança - enquanto o Miami bass, que predominou nos bailes funk, era mais rápido, incentivando movimentos mais vigorosos e pulos em danças individuais.

As coreografias em grupo funcionam melhor no começo do baile, quando ainda existe espaço para o desenvolvimento. Depois de uma hora no baile, a pista já está tomada por dançarinos, que não podem mais executar passos muito complicados sem esbarrar no grupo que está ao seu lado [...]. A música também começa a ficar mais empolgante e marcada, exigindo menos sutileza e mais animação do público. (VIANNA, 1987, p. 97) 
O momento de maior intensidade do baile se referia à hora em que músicas mais famosas, mais dançantes e ritmadas eram tocadas, como narra Frias (1976): "Quando se toca a canção Soul Power, de James Brown, quase um hino, a expressão Soul Power é repetida ritmicamente pelo público de ginásios lotados num sussurro, num murmúrio, num ruído surdo e homogêneo”. Nesse ponto culminante do baile, em que a dança se tornava mais vigorosa e a excitação atingia graus máximos, os corpos ficavam mais próximos e choques eram inevitáveis. Geralmente, nessas horas, era possível notar focos de briga e alguma violência, especialmente quando gangues ou galeras, como ficaram conhecidos mais recentemente grupos de jovens que praticavam certos tipos de delinquência nos bailes funks, aproveitavam para provocar e brigar com grupos rivais. "O DJ controla conscientemente a intensidade da festa. Até mesmo as batidas por minuto de cada música são levadas em consideração", como registrou Vianna (1987, p. 49) em um baile funk nos anos 1980. O controle exercido pelos disc-jóqueis também se dava no sentido de acalmar os ânimos. O DJ trabalhava aumentando a intensidade do baile e, após uma sequência mais agitada, desacelerava o ritmo dos dançarinos, tocando músicas mais lentas. Essa sucessão poderia ocorrer em vários momentos do baile, mas era uma estratégia frequentemente utilizada para fechar a festa no final das madrugadas. 